\title{
(ANTI)RETÓRICA EM GONÇALVES DE MAGALHÃES
}

\section{(ANTI)RHETORIC IN GONÇALVES DE MAGALHÃES}

\author{
Jean Pierre CHAUVIN ${ }^{1}$
}

\author{
“Nunca poeta foi hipócrita" (Junqueira Freire) ${ }^{2}$ \\ "[...] esse livro fez-se por si, naturalmente, \\ sem esforço" (Casimiro de Abreu) ${ }^{3}$ \\ “A interioridade agostiniana está por trás da virada \\ cartesiana, e o universo mecanicista foi \\ originalmente uma exigência da teologia" \\ ${\text { (Charles Taylor })^{4}}$
}

Resumo: O texto com que Gonçalves de Magalhães (1811-1882) apresenta Suspiros Poéticos e Saudades pretendia sintetizar premissas e valores da escola romântica. No entanto, embora o poeta se recusasse a seguir modelos da Antiguidade greco-latina e defendesse a honestidade com que compusera seus versos, tanto o "Prólogo" quanto os poemas do volume propiciam interpretação em chave inversa.

Palavras-Chave: Romantismo. Retórica. Gonçalves de Magalhães.

Abstract: In his presentation to Suspiros Poéticos e Saudades, Gonçalves de Magalhães (1811- 1882) intended to synthesise premises and values of the romantic school. However, despite refusing to follow Ancient greco-latin models and defending the honesty with which he wrote his verses, both "Prologue" and the poems in the volume offer an opposite key interpretation.

Keywords: Romanticism. Rhetoric. Gonçalves de Magalhães.

\section{Arqueologia}

Quem examinasse de perto os paratextos ${ }^{5}$ redigidos pelos poetas românticos, em meados do século XIX, no Brasil, constataria que havia neles pelo menos três elementos recorrentes: 1 . A negação das regras da tradição retórico-poética; 2. O enaltecimento da expressividade versificada por parte do $E u ; 3$. A evocação de Deus, em geral combinada com o elogio da Nação independente, em meio à declaração de sinceridade emotiva do Autor. Isso se verifica tanto nos

1 Professor de Cultura e Literatura Brasileira na Escola de Comunicações e Artes da USP; Doutorado em Letras (Teoria Literária e Literatura Comparada) pela Universidade de São Paulo. tupiano@usp.br

2 "Prólogo do Autor". In: Contradições Poéticas. Rio de Janeiro: Garnier, s/d., p. 4.

3 "Prólogo". In: As Primaveras. São Paulo: Martins Fontes, 2002, p. 6.

${ }^{4}$ As Fontes do Self. $3^{\mathrm{a}}$ ed. São Paulo: Edições Loyola, 2011, p. 407.

5 Cf. Gérard Genette. Paratextos editoriais. $2^{\mathrm{a}}$ ed. Trad. Álvaro Faleiros. Cotia: Ateliê, 2018. Revista Graphos, vol. 21, n² 2, 2019 | UFPB/PPGL | ISSN 1516-1536 
Primeiros Cantos, de Gonçalves Dias (1846), quanto na Lira dos Vinte Anos, de Álvares Azevedo (1853); tanto nas Primaveras, de Casimiro de Abreu (1859), quanto em O Estandarte Auriverde, de Fagundes Varela (1863). Em ensaio sobre Primeiros Cantos, Cilaine Alves Cunha (2003, p. 227) notou que:

\begin{abstract}
No Prefácio de Gonçalves Dias, o princípio de que a criação artística é interiormente gerada a partir da contemplação do belo natural e do pensamento de improviso parece apontar para a noção kantiana de que a arte resulta de um impulso desencadeado a partir do jogo estabelecido entre as faculdades sensíveis e espirituais do sujeito criador. Pressupõe-se aí que, no belo ou no sublime, predomina respectivamente uma harmonia e um conflito entre imaginação e razão, o que desemboca num "espontâneo" transbordamento do pensamento.
\end{abstract}

Neste artigo, propõe-se analisar e interpretar o "Prólogo" a Suspiros Poéticos $e$ Saudades, de Domingos José Gonçalves de Magalhães. Publicado em Paris em 1836, quase simultaneamente com a edição do primeiro tomo da Revista Niterói, o livro reúne cinquenta e cinco poemas - quarenta e três na primeira parte (Suspiros Poéticos), e doze na segunda (Saudades). O título dado ao volume não poderia ser mais decoroso: os versos são prenhes de interjeições e protestos de patriotismo daquele que se dizia poeta "peregrino". A exemplo do que sucede a outras obras, hoje empregadas quase exclusivamente como meras balizas temporais e estéticas, os manuais de literatura brasileira costumam referendar o ensaio de Gonçalves de Magalhães, publicado no primeiro tomo de Niterói, como marco inaugural do “nosso" Romantismo. Em 1939, por ocasião de uma edição comemorativa de Suspiros Poéticos e Saudades, Sérgio Buarque de Holanda assinalava que:

\begin{abstract}
Os Suspiros Poéticos quiseram ser a um tempo o nosso prefácio de Cromwell e o grito do Ipiranga da poesia. O manifesto que no mesmo ano publicava Magalhães em sua revista Nitheroy (...) reflete em um só movimento as duas aspirações. O fato de surgirem, livro e revista, em Paris, tem, por outro lado, um aspecto simbólico. Daí por diante será a França, não Portugal, o país que vai ditar as regras e modas que seguirão os nossos homens de cultura (HOLANDA, 1986, p. 15).
\end{abstract}

Inspirado nos pareceres de Ferdinand Dennis e Almeida Garrett (CÉSAR, 1978), sobre a literatura brasileira (em que o índio representaria o herói americano, em substituição aos mitos greco-latinos da Antiguidade) - ambos escritos em 1826 -, Gonçalves de Magalhães reafirmava a necessidade de os escritores da jovem nação substituírem a mitologia clássica pela mitologia cristã. Era imperativo escrever de nova maneira. A dicção "original" substituiria a "imitação" de modelos; a América, nova e emancipada, tomaria o lugar da Europa, antiga colonizadora; a "inspiração" tomaria o assento dos preceitos clássicos. De modo similar, o "Prólogo" à coletânea poderia ser considerado como uma espécie de síntese dos preceitos que orientavam a 
poesia do volume. Àquela altura, Gonçalves de Magalhães contava vinte e cinco anos e acabara de se formar em Medicina no Rio de Janeiro. Disposto a reforçar a ideia de que o seu livro inaugurasse um "novo" modo de conceber poesia, Gonçalves de Magalhães começa o texto de maneira originalíssima: o verbo "Lede" intitula o que poderia ser considerado uma "advertência" ao leitor ${ }^{6}$. Nas primeiras linhas, sugere analogias entre a arquitetura e a literatura. A "um pórtico ao Edifício" corresponderia "um prólogo ao Livro". Seria oportuno lembrar que Prefácios, Advertências, Prólogos e outros textos dedicados Ao Leitor, constituíam um gênero que remonta, no Ocidente, a séculos antes da era cristã ${ }^{7}$. Variedades dos proêmios, esses textos cumpriam diversas funções, dentre as quais, figurar o diálogo (mais ou menos sincero) entre autor e leitor; facultar a construção da captatio benevolentiae ${ }^{8}$, com base no discurso humilde do escritor; induzir o leitorado a interpretar e repercutir suas impressões sobre a obra, a partir das chaves de leitura recomendadas pelo poeta. Maria do Socorro Fernandes de Carvalho (2009, p. 13) recorda que o proêmio é o "[...] início do discurso, ocupando precisamente 'um lugar' em sua composição. Deve-se lembrar de que a divisão da matéria do discurso persuasivo - o lugar das partes: proêmio, narração, argumentação, refutação e peroração - é o artigo mais fundamental da retórica antiga".

Em Suspiros Poéticos e Saudades, a aproximação entre as artes demonstra engenho (algo curioso, sendo o poeta tão adepto do "natural"). Como se reforçasse a similitude entre a fachada de um edifício e o papel do texto introdutório, recorre a palavras trissílabas e de sonoridade similar. Nada mal, para quem advogava a supremacia das paixões, e da suposta espontaneidade, sobre a razão, sob o influxo do cálculo. Ao final do primeiro parágrafo, Magalhães defende-se de eventuais leitores "preconceituosos", decerto embalados por “espíritos apoucados” (MAGALHÃES, 1986, p. 39). Princípio nem tão modesto para quem pretendia afetar humildade e captar a benevolência alheia. Em seguida, o poeta afirmaria que se tratava de "um Livro de Poesias escritas segundo as impressões dos lugares" (MAGALHÃES, 1986, p. 39), sujeito, portanto, a oscilar quanto ao conteúdo, registro e forma,

\footnotetext{
${ }^{6}$ Ao referir-se ao "Prólogo" de Suspiros Poéticos e Saudades, assim se pronunciou José Veríssimo: "Essas páginas anódinas, mal pensadas e mal escritas, nada têm do ardor dos iniciadores ou neófitos da nova escola fora daqui" (VERÍSSIMO, 1963. p. 144).

${ }^{7}$ De acordo com Anne Cayela (1996, p. 215), “O prefácio é um gênero codificado em que a tópica evoluiu muito pouco ao longo dos séculos".

8 "A composição preambular é índice elegante do conhecimento e uso da língua cultivada no ócio dos homens de saber e indica domínio das formas de representação das virtudes civis e políticas. [...] Para isso, articulam comumente o antigo preceito da captatio benevolentiae, entendido como conquista da simpatia, atenção e docilidade do público. Essa convenção costuma agregar figuras retóricas de afetação de modéstia ou lugar de humildade, como a conhecida 'modéstia afetada' e a rusticitas, artifícios aproveitados, por sua vez, na esfera do discurso cristianizado por meio de figuras de devoção e humildade" (CARVALHO, 2009, p. 14-15).
}

Revista Graphos, vol. 21, n² 2, 2019 | UFPB/PPGL | ISSN 1516-1536 
sujeito a diferentes tempos, ações e lugares. No segundo parágrafo, evoca alguns dos pilares da estética romântica: poder divino ("grandeza de Deus"), representação da morte ("ciprestes que espalham sua sombra sobre túmulos"), destino "da Pátria", espontaneidade e movimento ("um Peregrino"). Os poemas materializariam as impressões de quem transitara por entre diferentes países da Europa, cujos versos variavam segundo "as cenas da Natureza".

Mas como assegurar que o livro fosse aceito como prova de sua "boa-fé?". Era preciso reforçar a hipótese de que se tratava de "poesias da alma e do coração" e que, consequentemente, deveriam ser interpretadas pelo mesmo viés com que teriam sido compostas - supondo que o livro encontraria "eco" da "alma nestas folhas". Para isso, o poeta se lançava aos "pés" (MAGALHÃES, 1986, p. 40) do público brasileiro, em potencial. Após propor que o leitor ordinário se identificasse com as paixões representadas no livro, Gonçalves de Magalhães passa à segunda seção de seu "Prólogo", de maneira a induzir um novo método de análise: "Para bem se avaliar esta obra, três coisas releva notar: o fim, o gênero, e a forma" (MAGALHÃES, 1986, p. 40). O discurso afeta didatismo, preocupação com o modo como a sua obra seria recebida e interpretada por aqui. A contradição é evidente: de um lado, impressionismo versificado; de outro, instruções com vistas a assegurar uma leitura que rumasse ao "absoluto".

Como era esperado, o poeta adverte que sua obra tem acento emotivo, embora a representação das paixões pressuponha a aplicação de técnicas da poética. Afirma temer a Deus, embora passasse os dias a viajar, em autêntica vida mundana e "errante" em diversos países do exterior. Atesta a conotação patriótica dos versos, embora estivesse, havia anos, longe de sua "saudosa" terra. Autointitulado patriótico e modernizador, embora situado no velho continente europeu, o poeta-andante ("peregrino") afirma que o objetivo maior de seu livro seria "elevar a Poesia à sublime fonte donde ela emana (...) indicando apenas no Brasil uma nova estrada aos futuros engenhos" (MAGALHÃES, 1986, p. 41). Para isso, Magalhães tentara, "empunhando a lira da Razão, (...) vibrar as cordas eternas do Santo, do Justo e do Belo" (MAGALHÃES, 1986, p. 41). A trinca de adjetivos não é fruto do acaso: Gonçalves de Magalhães introduz o critério de "santidade" entre as virtudes comuns ao gênero sublime - "justo" e "belo". Cilaine Alves Cunha (2003, p. 229-230) adverte que:

A [teoria] romântica toma a interioridade criativa do gênio imaginativo como o centro de onde emana a arte, sendo então prescrita como expressão de sua reflexão e sentimentos. A função predominante da obra de arte não é mais imitar qualidades e ações humanas típicas, nem ensinar deleitando, mas expressar, também por meio de artifícios adequados, os sentimentos que devem exteriorizar as lembranças retidas pela percepção sensorial, acrescentando à poesia o aspecto confessional e a dicção do solilóquio. O auditório ideal, nesse caso, torna-se o próprio poeta que, ao desqualificar 
a retórica, procura antes valorizar a sua originalidade e, assim, a invenção individual como força criadora.

Ao justapor "santidade", "justiça" e "beleza", sugeria a equiparação entre os valores preconizados pela fé católica àqueles que eram perseguidos não exclusivamente pelos poetas e filósofos, desde a antiguidade greco-latina. Ao acrescentar a qualidade do que seria "Santo" aos esteios da melhor tradição lírica, propõe o alinhamento de novos vértices a embalar o fazer poético. Por sinal, como o poeta evocara a temática religiosa, poucas linhas à frente tecerá ressalvas a Antônio Pereira de Sousa Caldas - embora o reconhecesse como "o primeiro dos nossos líricos". Contrariando as ideias de Rousseau e contestando a sua reverberação supostamente indevida, na poesia do sacerdote, lamenta que o poeta baiano "cantasse o homem selvagem de preferência ao homem civilizado", já que a civilização seria "obra de Deus" (MAGALHÃES, 1986, p. 41).

Gonçalves Magalhães era natural do Rio de Janeiro. Representante de incerta elite da jovem pátria brasileira, o recém-diplomado passaria quatro anos na Europa, a afetar saudade da pátria. Talvez distante das ruas fétidas da Corte brasileira, encontrasse melhor ambiente para elucubrar modos eficazes de defender a expressão romântica. O discurso nega o modo como procede. É divertido supor que a poesia romântica fosse uma espécie de "eflúvio" da alma e que o poeta negasse a fonte do Monte Hélicon, embora bebesse na tradição greco-latina. Em acordo com uma escala maior, rumo aos céus, Gonçalves de Magalhães elege o artista do verso como espécie moral de seu tempo: "O poeta sem religião, e sem moral, é como o veneno derramado na fonte” (MAGALHÃES, 1986, p. 42). A aproximação entre moral, ética e estética avançam. Além de vértice da arte poética, "santidade" passa a ser sustentáculo não só dos versos bons, elevados em direção a Deus, mas condição do sujeito que tenciona aderir ao Romantismo.

Trilhados os objetivos da poesia romântica, o escritor sugere que "determinado e conhecido o fim, o gênero se apresenta[ria] naturalmente". O seu método, portanto, seria espontâneo e substituiria a ideia de "fazer uma obra segundo a Arte", em que "imitar era o meio indicado; fingida era a inspiração, e artificial o entusiasmo" (MAGALHÃES, 1986, p. 43). Em suma, o fazer poético substituiria o artifício dos clássicos pela sinceridade do versejador moderno. Ora, nada mais ultrapassado, feio e pequeno que supor "que com Homero emparelhavam; como se pudesse parecer belo quem achasse algum velho manto grego, e com ele se cobrisse! Antigos e safados ornamentos, de que todos se servem, a ninguém honram" (MAGALHÃES, 1986, p. 43). 
Corroborando a ideia de que seu livro primava pela espontaneidade do registro, o impulso de Deus e amor da Pátria, o poeta alega se tratar de obra feita ao sabor do aleatório, graças à despreocupação com a ordem dos versos e o método como foram construídos: "Quanto à forma, isto é, à construção, por assim dizer, material das estrofes, e de cada cântico em particular, nenhuma ordem seguimos; exprimindo as ideias como elas se apresentaram, para não destruir o acento da inspiração" (MAGALHÃES, 1986, p. 43-44). Repare-se que a palavra "construção" aparece duas vezes no "Prólogo", o que parece contradizer o método supostamente "desordenado" do poeta. Tanto os seus versos revelam preocupação com a forma, quanto a sua disposição entre as duas partes do volume sugerem o contrário.

Ora, é justamente por enfileirar poemas datados em momentos diferentes e compostos em lugares variados que Suspiros Poéticos e Saudades revela ter sido concebido em acordo com um arranjo pré-determinado que visava simular, no teor dos versos, mas também em sua distribuição "aleatória" no volume, maior efeito de "sinceridade": palavra-chave do projeto romântico. Os artifícios, em nome do que chama de "natural", prosseguem. Se, no primeiro parágrafo, Gonçalves de Magalhães comparara a poesia com a arquitetura, agora sugere sua analogia com a música, com vistas a driblar a monotonia dos sons e o ritmo simétrico dos versos: "não se compõe uma orquestra só com sons doces e flautados; cada paixão requer sua linguagem própria, seus sons imitativos, e períodos explicativos" (MAGALHÃES, 1986, p. 44).

Escamoteando a persona de homem letrado, bem formado, jovem, rico e engenhoso, o poeta sugere que só contaria com duas espécies de leitores. Aqueles que o lessem "de boa-fé" poderiam "colher uma pérola no meio das ondas". Já aqueles que se aproximassem com "olhos de prisma" agiriam "como as serpentes", que "sabem converter em veneno até o néctar das flores" (MAGALHÃES, 1986, p. 45). Nesse sentido, o maniqueísmo participa do "Prólogo" e dos versos. Somente os leitores maliciosos, contaminados pela peçonha, seriam imunes a seus versos, inspirados pela bondade e honestidade, pois sua aproximação datada, calculista e minuciosa seria incompatível com uma poesia que emanava “do coração e da alma", como já vimos.

Para além do temor a Deus e a rejeição da cultura clássica, o autor afirma que a sua obra pagaria "um tributo à Pátria". Nas linhas finais, estabelece diálogo figurado com o livro, como se estivesse a traçar e prever o melhor caminho para a poesia que continha: "Tu vais, ó Livro, ao meio do turbilhão em que se debate nossa Pátria; onde a trombeta da mediocridade abala todos os ossos, e desperta todas as ambições; onde tudo está gelado, exceto o egoísmo" 
(MAGALHÃES, 1986, p. 45). Sim, o livro (personificação do próprio poeta) seguiria: “cheio de amor pela Pátria, de entusiasmo por tudo o que é grande, e de esperanças em Deus, e no futuro" (MAGALHÃES, 1986, p. 46). Não será demasiado supor que o volume "peregrinaria" em meio a uma terra de medíocres - sina que o poeta procurara contornar sob o abrigo do velho continente.

\section{Arte}

A leitura atenta do "Prólogo" de Suspiros Poéticos e Saudades bastaria para mostrar que a simplicidade do poeta é fingida. Embora negasse seguir os modelos da tradição clássica ${ }^{9}$, Gonçalves de Magalhães lança mão de tópicas que remontavam a séculos de existência, já em seu tempo. É o que revela, por exemplo, o ato de se postar "aos pés" dos leitores - em que recorre a uma canônica fórmula de humildade, utilizada tanto pelo poeta, em 1836, quanto por Antônio Vieira, em meados do século XVII, ao enviar cartas a pessoas de posição superior. Longe de ser fruto da espontaneidade, ou brotar das impressões aligeiradas do poeta "peregrino", o texto introdutório revela artifício e acentua o caráter programático do livro ${ }^{10}$. Publicado no mesmo ano em que saíra o Ensaio sobre a História da Literatura do Brasil, na Revista Niterói, esse segundo livro de Gonçalves de Magalhães integrava o projeto de filiação ao romantismo francês e português, que ele pudera conferir in loco, em companhia de Araújo Porto Alegre e Francisco de Sales Torres Homem. É deste último o comentário sobre Suspiros Poéticos e Saudades, quando da primeira edição do livro do amigo, em Paris:

\footnotetext{
Desde os princípios do século atual uma grande reação começou a abalar os antigos fundamentos do reino místico das musas. O vago das lembranças do berço da civilização moderna, os sublimes pensamentos do Cristianismo, a simplicidade das cenas da natureza, que tão tocantes relações oferecem com as misérias do nosso coração, pareceram uma fonte de emoções mais delicadas e verdadeiras que os engenhosos sonhos da Antiguidade (TORRES HOMEM, 1986, p. 33). ${ }^{11}$
}

\footnotetext{
9“Nas poesias iniciais de Magalhães, nota-se frequentemente a influência dos árcades; nas seguintes, o abuso dos antigos modelos leva-o a acercar-se de um 'novo maravilhoso'. Nisso está o ponto de partida do seu romantismo" (HOLANDA, 1986, p. 20).

${ }^{10}$ Aplica-se à temática nacionalista, privilegiada por Gonçalves de Magalhães, o que Cilaine Alves Cunha (2003, pp. 240-241) percebeu a respeito do apagamento da obra de Gonçalves Dias, como produto ultrapassado e fora do compasso que confunde modernização com negação do passado: "O esquecimento de suas poesias pela recepção atual tampouco se deve apenas ao fato de que a supremacia das nações interessou apenas enquanto interessava às elites econômicas, locais e internacionais em sociedade, formar mercados internos e criar uma jurisdição comercial nos limites de fronteiras circunscritas para que, com isso, as mercadorias circulassem e o sistema se expandisse". 11“Esse juízo encomiástico, para quem leia hoje os Suspiros Poéticos e Saudades, mesmo para quem os lia no século passado [XIX], depois, talvez, de uns vinte anos de sua publicação, parece simplesmente o produto da amizade, da participação na mesma confraria literária" (BARROS, 1973, p. 77).
}

Revista Graphos, vol. 21, n², 2019| UFPB/PPGL | ISSN 1516-1536 
O artigo de Torres Homem reverberará no que dirão os críticos. A poesia de Magalhães é saudada como beata, natural, patriótica, nova e sincera; mas, embora o poeta negasse o emprego de artifícios e afirmasse desobedecer os modelos antigos, não despreza a forma. Por sinal, estrutura o "Prólogo" com múltiplos objetivos: sintetizar o teor do programa romântico, em curso; induzir a leitura do público; reforçar os votos com a religião oficial do Império; acentuar a ideologia patriótica, como maior alcance e penetração de uma literatura dita nacional. Como observou Maria Orlanda Pinassi:

\footnotetext{
Com a publicação da revista e do poema de Magalhães, começavam a provar o gosto da notoriedade entre figuras importantes da Corte, notoriedade que seria uma marca de seu papel intelectual durante quase todo o Império: Gonçalves Magalhães seria Visconde de Araguaia, Porto Alegre, Barão de Santo Ângelo e Torres Homem, Visconde de Inhomirim (PINASSI, 1998, p. 18-19).
}

A tradição poética não só reverbera, mas também contagia os versos convencionais de Gonçalves de Magalhães. Comecemos pela tópica da vita brevis horaciana, facilmente detectável nos versos de "A Beleza”:

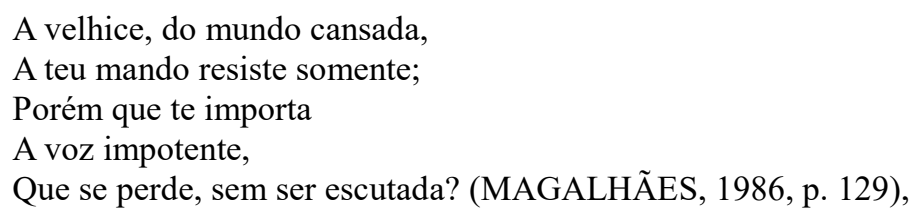

Estruturado em quintetos, "A Beleza" contradiz a falta de projeto, anunciada pelo poeta no "Prólogo". Repare-se na alternância entre eneassílabos (no primeiro, segundo e quinto versos) e pentassílabos (no terceiro e quarto versos), o que confere um ritmo binário ao texto. Essa oscilação na medida dos versos se repete nas dez estrofes do poema e parece reforçar o jogo de perguntas e respostas sugerido ao longo dos cinquenta versos:

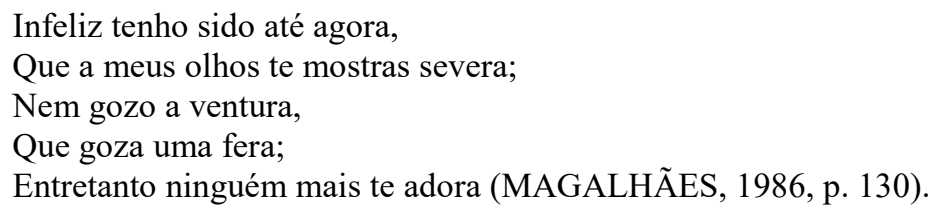

Algo de similar se verifica em “A Tristeza”, décimo quarto poema do livro:

Triste sou como o salgueiro

Solitário junto ao lago,

Que depois da tempestade

Mostra dos raios o estrago (MAGALHÃES, 1986, p. 147). 
Integralmente disposto em quartetos, todos os versos são heptassílabos e tentam comover o leitor mais duro. A quinta e última quadra evidencia o teor contraditório do que o eu lírico afirma. Embora afirme esperar pela morte, como "lenitivo", persiste em versejar, sem descuidar o ritmo dos versos, nem a alternância entre rimas, a justapor o primeiro com o terceiro e o segundo com o quarto versos:

\author{
Do mundo já nada espero, \\ Nem sei por que inda vivo! \\ Só a esperança da morte \\ Me causa algum lenitivo (MAGALHÃES, 1986, p. 148).
}

A saudade é um dos temas-chave do livro. Para abordar o motivo sob variada perspectiva, Gonçalves de Magalhães também presta homenagens aos velhos amigos, inclusive aqueles deixados na "pátria". É o que se lê no poema "XXV - Ao Meu Ilustre Mestre e Amigo / O Reverendíssimo Senhor / Fr. Francisco de Monte-Alverne":

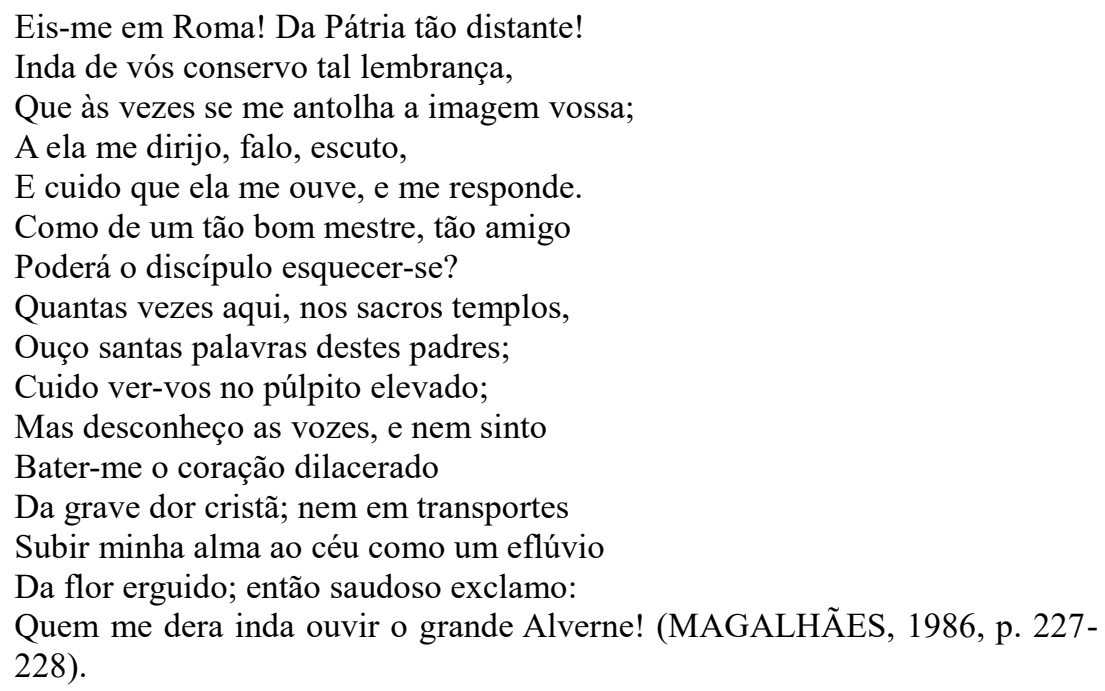

Estruturado em decassílabos, o poema aproxima-se formalmente de uma carta familiar, endereçada sob a forma de versos, ao frei - situado na "Pátria" comum, mas "tão distante". Repare-se: a opção pelas décimas não parece fruto de "impressões" ou palavras feitas ao sabor do acaso. Gonçalves de Magalhães parece aplicar as antigas lições da poética, que recomendavam adequar o tema ao gênero e às medidas do poema:

Embalde Roma invoco, e a musa empenho,

Para um quadro traçar destes prodígios;

Sem cessar uma voz me fala n'alma:

Da louca pretensão que te alucina,

Desiste, oh fantasia! não te é dado

Achar uma linguagem tão facunda,

Tão sublimes imagens com que pintes

Dignamente esta imensa maravilha (MAGALHÃES, 1986, p. 228).

Revista Graphos, vol. 21, n² 2, 2019 | UFPB/PPGL | ISSN 1516-1536 
Embora o poeta reitere que os versos de Suspiros Poéticos e Saudades fossem inspirados nas "circunstâncias", a matéria de seus poemas invariavelmente combina memória e tradição, ainda que "Embalde Roma" invoque. O eu lírico sugere não ser capaz de empregar uma linguagem à altura de assunto tão elevado. Expediente semelhante será encontrado na segunda quadra do poema “XXX - No Álbum De Uma Veneziana”, destinado a uma "bela virgem":

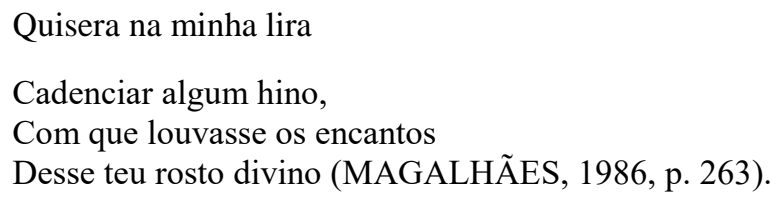

De que trata o poema? Mais uma vez, o eu lírico afirma que os seus parcos meios de expressão não lhe permitem "louvar os encantos" da homenageada, com "rosto divino". Duas estrofes mais e o poeta redige a estrofe nestes termos:

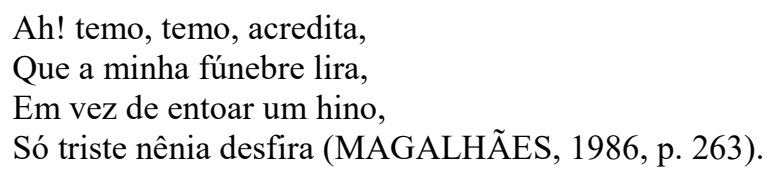

Por acaso, a repetição do verbo "temer" guardaria relação com as imagens que se imprimiram tão fortemente na alma e peito do nosso "vate"? Mistério insondável, para além da discussão em torno da cota de verdade, porventura embutida no poema. De que elementos dispomos? A matéria dos versos é lírica e envolve os afetos do eu lírico por uma mulher. Talvez, por esse motivo, Gonçalves de Magalhães redija o poema em quadras septissílabas, como se pretendesse corroborar o vínculo entre tema, gênero e quantidade de sílabas métricas. Atentese, ainda, para as rimas finais: elas aproximam, em todas as estrofes, o segundo e o quarto versos.

\section{Projeto}

Nada menos "impressionista" ou "de boa-fé" que um projeto (calculado) e de cunho ambicioso, redigido mediante a confortável distância em relação ao país onde ele nascera e se formara. Não será demasiado lembrar que a Revista Niteró $i^{12}$ e o livro, ambos editados na

\footnotetext{
12“'Carregando de culpa as empresas do colonizador português, baseadas sobretudo em formas de opressão estética e material, na revista Niterói é proposta uma ruptura com os valores coloniais, representados principalmente pelas normas clássicas e universalizantes que impediam a manifestação das particularidades brasileiras do espírito e da natureza. O passado, portanto, deveria ser corrigido mas, para isso, era mister abandonar a cultura da imitação e da generalização imposta pelos padrões portugueses" (PINASSI, 1998, p. 22).
}

Revista Graphos, vol. 21, n² 2, 2019 | UFPB/PPGL | ISSN 1516-1536 
França, circularam imediatamente no Brasil. No ensaio de Gonçalves de Magalhães, lê-se o seguinte:

\begin{abstract}
A poesia brasileira não é uma indígena civilizada; é uma grega vestida à francesa e à portuguesa e climatizada no Brasil; é uma virgem do Hélicon que, peregrinando pelo mundo, estragou seu manto, talhado pelas mãos de Homero, e sentada à sombra das palmeiras da América, se apraz ainda com as reminiscências da pátria, cuida ouvir o doce murmúrio da Castália, o trépido sussurro do London e do Ismeno, e toma por um rouxinol o sabiá que gorjeia entre os galhos da laranjeira (MAGALHÃES, 2014, p. 100).
\end{abstract}

Dessa forma, tanto o ensaio veiculado no periódico, em 1836, quanto o "Prólogo" e os poemas do livro serviriam como cartão de visitas em etapa posterior, quando da maior aproximação entre Gonçalves de Magalhães e Dom Pedro II. Em acordo com a síntese de Lilia Schwarcz (1999, p. 137-138):

[...] d. Pedro II, um jovem rei de 22 anos, vivia no "melhor dos mundos". Com a recente estabilidade política e financeira, obtida mediante a entrada do café brasileiro no mercado internacional, convertia-se no centro das atenções: o maestro da cena cultural, o pêndulo das decisões políticas. É esse o momento em que o imperador assumirá uma postura mais ativa junto ao Instituto Histórico e Geográfico Brasileiro e procurará formar uma geração de intelectuais e de artistas - segundo Freyre, tão jovens como ele -, que passarão a refletir sobre uma nacionalidade brasileira. É a época do indigenismo de fundo romântico, dos quadros grandiosos da Academia Imperial de Belas-Artes, dos exames no Colégio Pedro II. O imperador transformavase aos poucos em um "monarca tropical".

Sob tal perspectiva, a criação do Instituto Histórico e Geográfico Brasileiro, em 1838, pode ser considerada mais uma etapa do projeto de uma nação que caminhava tropegamente sobre o frágil assoalho da Independência e precisava reforçar a sua identidade no âmbito político e cultural. Lucia Maria Paschoal Guimarães (2011, p. 33) relembra que:

Em meio a tantas crises institucionais e às notícias de revoltas que agitavam o país, a
Corte do Rio de Janeiro assistiu, no decorrer de 1838, à instalação de dois importantes
centros da Memória Nacional. O primeiro, o Arquivo Público, criado em 2 de janeiro
daquele ano, por ato do Ministro Bernardo Pereira de Vasconcellos. O segundo, tarde,
em 21 de outubro, tratava-se de um empreendimento de caráter privado, que contava
com o patrocínio da Sociedade Auxiliadora da Indústria Nacional. Sua fundação
decorrera de uma proposição encaminhada ao Conselho Administrativo da Sociedade
Auxiliadora, por iniciativa do Marechal Raymundo José da Cunha Matos e o Cônego
Januário da Cunha Barbosa, que justificavam a nova instituição alegando o seu caráter
pedagógico.

Como se sabe, nas décadas seguintes, Dom Pedro II passaria a admirá-lo e defendê-lo, inclusive nos jornais da Corte, elegendo Domingos José Gonçalves Magalhães lídimo portavoz da literatura nacionalista; quase um brasão literário: ícone do Segundo Império. Sob essa ótica, o ruído suscitado pela controvérsia entre José de Alencar e Gonçalves de Magalhães, em 
torno da Confederação dos Tamoios, terá rendido eloquente murmuração na Corte enlameada do Rio de Janeiro. Mas, afora as disputas veiculadas em jornais e comentadas nos cafés, o saldo terá sido menor do que pretende certa crítica. De certo modo, Dom Pedro II reeditava o mecenatismo de Sebastião José de Carvalho e Melo, durante o reinado de Dom José I, entre 1750 e 1777 (TEIXEIRA, 1999). No âmbito oficial, empenhado em dar maior representatividade aos poetas que orbitavam em torno do palácio, a proteção do imperador será levada às últimas consequências, na década de 1850. É sintomático que, no mesmo ano, tenha sido criada a Revista Guanabara, sob a direção de Porto Alegre, Gonçalves Dias e Joaquim Manuel de Macedo. Em 1856, é publicado o célebre poema épico de temática indianista, $A$ Confederação dos Tamoios, pelo mesmo Gonçalves de Magalhães, agora sob o incentivo político, cultural e pecuniário do próprio imperador. ${ }^{13}$

Após intenso debate nos jornais da Corte ${ }^{14}$, em torno do épico de Magalhães, o fato é que, ao final da vida, tanto José de Alencar - desgostoso com o fato de ter sido preterido por Dom Pedro II ao posto no Senado -, quanto o protegido máximo do Imperador, Gonçalves de Magalhães, findariam seus dias sob o auspicioso manto da vida pública: um, recolhido em suas largas terras; outro, tão "patriótico" que trocara o novo mundo americano - cenário ideal para a nova poesia romântica - pela vetusta Europa. A trajetória de Gonçalves de Magalhães reforça a premissa de que a "sinceridade" continuava a ser afetação de homem letrado, sequioso por ampliar o seu leitorado e exercer maior influência junto aos círculos de poder. É que, em seu caso, a honestidade não passava de um atributo do ethos, capaz de lhe render o título de Visconde do Araguaia: autêntica mercê concedida pelo Império. Não seria demasiado lembrar que poesia é, substancialmente, artifício. E o poeta não estava sozinho no projeto românticonacionalista de vincular a arte à suposta honestidade e produzir efeito de verdade, a bem do leitor e segundo as vontades emanadas do trono imperial. A exemplo do que acontecia com seus conterrâneos, em Gonçalves de Magalhães a "saudade" era, quase sempre, substantivo abstrato. Quanto aos "suspiros", pouco ultrapassavam o plano formal da interjeição, ainda que o poeta negasse com veemência as regras da poesia e declarasse absoluta sinceridade.

\footnotetext{
13 “'Retornando, de certa forma, ao modelo do 'bom selvagem' de Rousseau, Magalhães construía sob encomenda, o que deveria ser o maior épico nacional centrado na figura dos heróis indígenas, com seus atos de bravura e gestos de sacrifício. Tentando fundir a 'excentricidade romântica com a pesquisa histórica', esse autor acreditava ser possível superar as especificidades regionais para se chegar a um mito nacional de fundação" (SCHWARCZ, 1999, p. 206).

${ }^{14}$ Lê-se na segunda carta escrita por Alencar: "No retrato do herói, querendo dar uma ideia de sua ligeireza em atirar ao arco, o Sr. Magalhães ficou, para mim, aquém de J. Basílio da Gama, no seu poemeto do Uraguai. Há neste último mais simplicidade de forma, e ao mesmo tempo mais energia de pensamento" (ALENCAR, 2014, p. 435).
} 


\section{Referências}

ABREU, Casimiro José Marques de. As primaveras. São Paulo: Martins Fontes, 2002.

ALENCAR, José de. Carta Segunda. In: SOUZA, Roberto Acízelo de (org.). Historiografia da literatura brasileira: textos fundadores (1825 - 1888). Rio de Janeiro: Caetés, 2014. p. $90-108$, p. $431-440$.

BARROS, Roque Spencer Maciel de. A significação educativa do romantismo brasileiro: Gonçalves de Magalhães. São Paulo: Grijalbo; Edusp, 1973.

CARVALHO, Maria do Socorro Fernandes de. Preambulares do livro seiscentista em Portugal e no Brasil. Teresina: Editora Universitária da UFPI; Fapepi, 2009.

CAYUELA, Anne. Le paratexte au Siècle d'Or: prose romanesque, livres et lecteurs en Espagne au XVII siècle. Genebra: Droz, 1996.

CÉSAR, Guilhermino. Historiadores e críticos do romantismo: 1 - a contribuição europeia: crítica e história literária. São Paulo: Edusp, 1978.

CUNHA, Cilaine Alves. Ativismo neoclássico de Gonçalves Dias. Revista língua e literatura, n. 27, São Paulo: FFLCH-USP, 2003. p. 225-243.

FREIRE, Luís José Junqueira. Obras completas - Tomo II: contradições poéticas. $4^{\mathrm{a}}$ ed. Rio de Janeiro: Garnier, s/d.

GENETTE, Gérard. Paratextos editoriais. $2^{\mathrm{a}}$ ed. Tradução de Álvaro Faleiros. Cotia: Ateliê, 2018.

GUIMARÃES, Lúcia Maria Paschoal. Debaixo da imediata proteção imperial: Instituto Histórico e Geográfico Brasileiro (1838-1889). São Paulo: Annablume, 2011.

HOLANDA, Sérgio Buarque de. Prefácio. In: GONÇALVES MAGALHÃES, Domingos José. Suspiros poéticos e saudades. $5^{\text {a }}$ ed. Brasília: Editora da UnB; INL, 1986. p. 13-32.

MAGALHÃES, Domingos José Gonçalves. Suspiros poéticos e saudades. $5^{\mathrm{a}}$ ed. Brasília: Editora da UnB; INL, 1986.

Discurso sobre a História da Literatura do Brasil. In: SOUZA, Roberto Acízelo de (org.). Historiografia da literatura brasileira: textos fundadores (1825 - 1888). Rio de Janeiro: Caetés, 2014. p. 90-108.

PINASSI, Maria Orlanda. Três devotos, uma fé, nenhum milagre. São Paulo: Editora UNESP, 1998.

SCHWARCZ, Lilia Moritz. As Barbas do Imperador: D. Pedro II, um monarca nos Trópicos. $2^{\mathrm{a}}$ reimp. São Paulo: Companhia das Letras, 1999.

TAYLOR, Charles. As fontes do self: a construção da identidade moderna. $3^{\mathrm{a}}$ ed. Tradução de Adail Ubirajara Sobral; Dinah de Abreu Azevedo. São Paulo: Edições Loyola, 2011. 
TEIXEIRA, Ivan. Mecenato pombalino e poesia neoclássica. São Paulo: Edusp, 1999.

TORRES HOMEM, Francisco de Sales. Artigo. In: GONÇALVES MAGALHÃES,

Domingos José. Suspiros Poéticos e Saudades. 5ª ed. Brasília: Editora da UnB; INL, 1986. p. 33-37.

VARELA, Luís Nicolau Fagundes. Poesias Completas. São Paulo: Edição Saraiva, 1956.

VERÍSSIMO, José. História da Literatura Brasileira. 4ª ed. Brasília: Editora da UnB, 1963.

Recebido em: 20/08/2019

Aceito para publicação em: 29/09/2019 